\title{
Non-alcoholic fatty liver disease in patients infected with human immunodeficiency virus: a systematic review
}

1. Faculdade de Medicina da Bahia - Universidade Federal da Bahia (UFBA), Salvador, BA, Brasil. 2. Escola de Nutrição - Universidade Federal da Bahia (UFBA), Salvador, BA, Brasil. 3. NASH Study Group - Universidade Federal da Bahia (UFBA), Salvador, BA, Brasil.

\section{SUMMARY}

OBJECTIVE: To evaluate the prevalence of nonalcoholic fatty liver disease (NAFLD) in patients with HIV/AIDS.

METHODS: The systematic review included articles indexed in MEDLINE (by PubMed), Web of Science, IBECS, and LILACS. Studies eligible included the year of publication, diagnose criteria of NAFLD and HIV, and were published in English, Portuguese, or Spanish from 2006 to 2018. The exclusion criteria were studies with HIV-infection patients and other liver diseases. Two reviewers were involved in the study and applied the same methodology, according to PRISMA (Preferred Reporting Items for Systematic Reviews and Meta-Analyses).

RESULTS: One hundred and sixteen papers were selected, including full articles, editorial letters, and reviews. Twenty-seven articles were excluded because they did meet the inclusion criteria. A total of 89 articles were read, and 13 were considered eligible for this review. Four case series used imaging methods to identify NAFLD, and nine included histology. The prevalence of NAFLD in HIV-patients ranged from 30\%-100\% and, in nonalcoholic steatohepatitis (NASH), from $20 \%$ to 89\%. A positive association between dyslipidemia, insulin resistance, and body mass index was observed. There was no agreement between the studies that evaluated the relationship between antiretroviral drugs and NAFLD.

CONCLUSION: This systematic review showed a high prevalence of NAFLD in HIV-patients, which was associated with metabolic risk factors. The possible association between antiretroviral therapy and NAFLD needs further studies.

KEYWORDS: Non-alcoholic fatty liver disease. HIV infections. Acquired Immunodeficiency Syndrome.

\section{INTRODUCTION}

Acquired Immunodeficiency Syndrome (AIDS) is caused by a retrovirus of the lentivirus family. This virus is transmitted mainly by sexual contact, parenterally, or through vertical transmission in infected pregnant women. According to the Joint United Nations Program on Human immunodeficiency virus (HIV)/AIDS (2016), there were 36.7 million individuals living with HIV worldwide. Access to antiretroviral 
therapy (ART) led to an increase in life expectancy, and it was estimated that 5.8 million people over the age of 50 years were living with HIV in $2015^{1}$.

Liver diseases are a frequent cause of death unrelated to AIDS in these individuals. Abnormal liver enzymes are common in HIV-infected patients, even in the absence of other causes of liver disease, such as viral hepatitis or alcohol abuse. Co-infection with the hepatitis $\mathrm{C}$ virus (HCV) is very common, justifying the expressive relationship between HIV and liver disease deaths. However, NAFLD or NASH also has been reported in patients with HIV. These patients have presented an elevated prevalence of NAFLD/NASH and clinical manifestations of this liver disease ${ }^{2}$.

The prevalence of NAFLD around the world is estimated in $25-30 \%$ of the population ${ }^{3}$. NAFLD has a broad spectrum, including hepatic steatosis and NASH, with the potential for progression to fibrosis, cirrhosis, and hepatocellular carcinoma ${ }^{2,3}$. Obesity is the main risk factor, and, therefore, NAFLD has become frequent in all populations ${ }^{4,5}$.

In patients with HIV, as in the general population, NAFLD is associated with increased waist circumference (WC), low HDL levels, high triglyceride levels, and insulin resistance. Moreover, the potential impact of metabolic factors combination with antiretroviral therapy or direct HIV effects on the emergence of NAFLD needs to be evaluated ${ }^{6}$.

This systematic literature review evaluated the prevalence of NAFLD in patients with HIV/AIDS

\section{METHODOLOGY}

The review included articles indexed in the MEDLINE (through access to the PubMed), SciELO, IBECS, and LILACS databases. A search was also done based on the references of the articles found. Articles published in English, Portuguese, or Spanish were included from 2006 to 2018.

The descriptors were initially checked on the Virtual Health Library website (http://decs.bvs.br/) and the National Center for Biotechnology Information (https://www.ncbi.nlm.nih.gov/mesh) in order to use the most appropriate terminology to exclude other diseases that occur with hepatic steatosis. The descriptors "Nonalcoholic Fatty Liver Disease" and "HIV" were crossed using the Boolean operator "AND" through the Medical Subject Heading (MeSH) interface. Eligible studies included cross-sectional studies in humans. Review articles, updates, case reports, editorial letters, studies with HBV/HCV co-infected patients, and experimental studies were excluded. Two reviewers participated in the study using the same methodology according to the Preferred Reporting Items for Systematic Reviews and Meta-Analyseses (PRISMA).

\section{RESULTS}

One hundred and sixteen papers were selected, including full articles, editorial letters, and reviews. After applying the filters for time, languages, and delimitation of studies in humans, 27 documents were excluded because they did not fit into the inclusion criteria, or they were duplicated. A total of 89 articles were read, and 77 documents were excluded: 30 review articles, 22 with content irrelevant to the objective of this study, 10 editorial letters, and 11 articles involving HIV/HCV/HBV coinfection studies, three updates, and one experimental study. Two articles were added after a search based on the bibliographic references. Thirteen articles were included in this review (Figure 1).

Table 1 shows the prevalence of NAFLD and NASH in 11 and 12 studies, respectively. Just over half of the studies were conducted in the USA and Canada ${ }^{2,8-13}$. The three largest series used imaging tests, such as computed tomography (CT) or ultrasonography (USG) or Magnetic resonance to identify hepatic steatosis ${ }^{11,14-16}$. The smaller series used hepatic biopsy, which is considered a gold standard for the diagnosis and staging of NAFLD/NASH ${ }^{2,8-10,12,13,17,18}$.

FIGURE 1. ALGORITHM OF ARTICLES SELECTION.

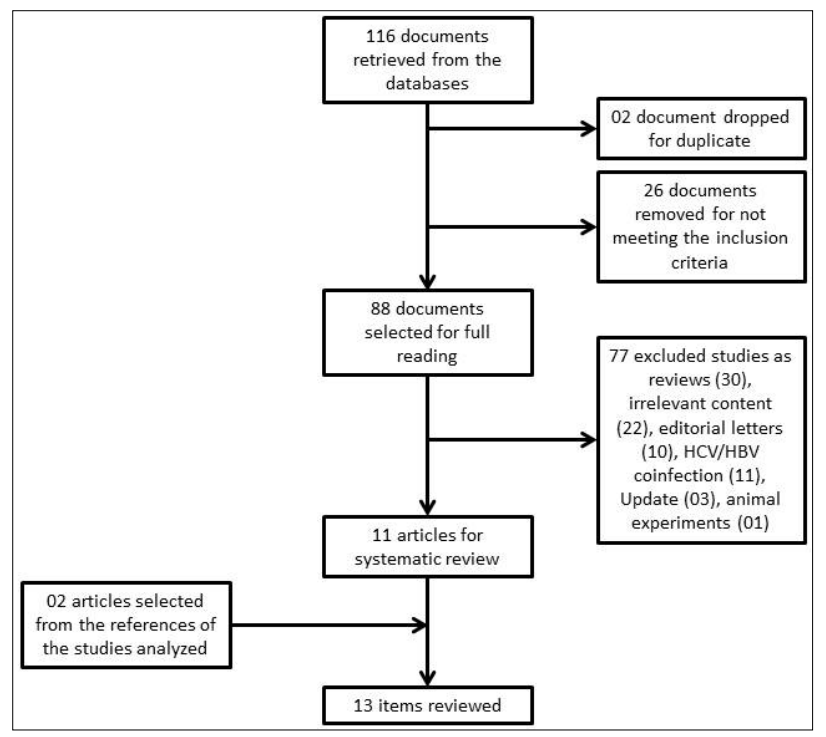


The prevalence of NAFLD in the HIV-positive population ranged from $30 \%$ to $100 \%$ and NASH from $20 \%$ to $89 \%$.

The study by Price et al. ${ }^{19}$ was not considered to assess prevalence due to the selection of 719 patients without distinction from patients coinfected with HBV or HCV. However, after adjusting for the NAFLD confounding variables, this study was included in Table 2 , which specifically assessed the associated factors.
The selection of patients in the many studies did not occur in the same way, and this aspect directly interfered with the prevalence findings. Figure 2 shows the studies according to the sample selection method.

The evaluation of the main variables studied in 11 of 13 studies can be identified in Table 2 . A positive association was found for insulin resistance (IR) or diabetes mellitus (DM) in six of seven studies ${ }^{6,8,15-17,19}$,

TABLE 1. PREVALENCE OF NONALCOHOLIC FATTY LIVER DISEASE AND NONALCOHOLIC STEATOHEPATITIS IN PATIENTS INFECTED WITH HIV ALONE

\begin{tabular}{|c|c|c|c|c|c|}
\hline \multirow[t]{2}{*}{ Reference } & \multirow[t]{2}{*}{ Country } & \multirow[t]{2}{*}{ Diagnostic Method } & \multirow[t]{2}{*}{$\mathrm{N}$} & \multicolumn{2}{|c|}{ Prevalence } \\
\hline & & & & NAFLD & NASH \\
\hline Perez et al., $2018^{14}$ & Spain & Magnetic resonance & 72 & $33,3 \%$ & - \\
\hline Morse et al., $2015^{8}$ & USA & Biopsy & 62 & $73 \%$ & $54 \%$ \\
\hline Vodkin et al., $2015^{2}$ & USA & Biopsy & 86 & $38 \%$ & $24 \%$ \\
\hline Nishijima et al., $2014{ }^{15}$ & Japan & Ultrasonography & 485 & $31 \%$ & - \\
\hline Rivero-Juarez et al., $2013{ }^{17}$ & Spain & Biopsy & 10 & $100 \%$ & $20 \%$ \\
\hline Sterling et al., $2013^{9}$ & USA & Biopsy & 14 & $64 \%$ & $28 \%$ \\
\hline Arendt et al., $2011^{10}$ & Canada & Biopsy & 20 & $30 \%$ & $70 \%$ \\
\hline Crum-Cianflone et al., $2009^{11}$ & USA & Ultrasonography & 216 & $31 \%$ & $20 \%^{*}$ \\
\hline Ingiliz et al., 200918 & France & Biopsy & 30 & $60 \%$ & $89 \%$ \\
\hline Akhtar et al., $2008^{12}$ & USA & Biopsy & 23 & $56 \%$ & $39 \%$ \\
\hline Guaraldi et al., $2008^{16}$ & Italy & Computer Tomography & 225 & $36 \%$ & - \\
\hline Mohammed et al., $2007^{13}$ & Canada & Biopsy & 26 & $100 \%$ & $55 \%$ \\
\hline
\end{tabular}

* The study by Crum-Cianflone used biopsies from 55 patients. NAFLD: nonalcoholic fatty liver disease; NASH: nonalcoholic steatohepatitis; HIV: human immunodeficiency virus

TABLE 2. CLINICAL CONDITIONS AND LABORATORY ABNORMALITIES ASSOCIATED WITH NONALCOHOLIC FATTY LIVER DISEASE IN MONO-INFECTED HIV PATIENTS.

\begin{tabular}{|c|c|c|c|c|}
\hline Reference & Country & Diagnostic Method & $N$ & Clinical Conditions and Laboratory changes \\
\hline Morse et al., $2015^{8}$ & USA & Biopsy & 62 & $\begin{array}{l}\text { IR/DM (+); Hepatic steatosis (+); Aminotransferases elevation (+); } \\
\text { Polymorphyms PNPLA3. }\end{array}$ \\
\hline Vodkin et al., $2015^{2}$ & USA & Biopsy & 86 & $\begin{array}{l}\text { Dyslipidemia (+); aminotransferases elevation (+); Canalicular } \\
\text { enzymes (+); ART (-); HIV (+) }\end{array}$ \\
\hline Nishijima et al., $2014{ }^{15}$ & Japan & Ultrasonography & 485 & $\begin{array}{l}\text { IR/DM (-); BMI/WC (+); Dyslipidemia (+), hypertriglyceridemia } \\
\text { and elevated LDL levels; aminotransferases elevation (+), elevated } \\
\text { ALT; ART (-);Elevated CD4+ (+) }\end{array}$ \\
\hline Price et al., $2014{ }^{19}$ & USA & Computer Tomography & 719 & $\begin{array}{l}\text { IR/DM (+); BMI/WC (+); Elevation of aminotransferases (+), } \\
\text { elevated ALT; ART (+), greater cumulative exposure to Dideoxynu- } \\
\text { cleoside analogues (Stavudina, Didanosine, Zalcitabine); HIV (-); } \\
\text { CD4+(-) }\end{array}$ \\
\hline $\begin{array}{l}\text { Rivero-Juarez et al., } \\
2013^{17}\end{array}$ & Spain & Biopsy & 10 & $\begin{array}{l}\text { IR/DM (+); BMI/WC (+); Dyslipidemia (+), hypertriglyceridemia; } \\
\text { Hepatic steatosis (+); ART (-); CD4+ plus hypertriglyceridemia (+) }\end{array}$ \\
\hline Sterling et al., $2013^{9}$ & USA & Biopsy & 14 & IR/DM (+); Canalicular enzymes (+) plus hypertriglyceridemia \\
\hline $\begin{array}{l}\text { Crum-Cianflone et al., } \\
2009^{11}\end{array}$ & USA & Ultrasonography & 216 & $\begin{array}{l}\text { BMI/WC plus Hypertriglyceridemia (+); Dyslipidemia (+), hypertri- } \\
\text { glyceridemia and decreased HDL levels; ART (-); HIV (-); CD4+(-) }\end{array}$ \\
\hline Ingiliz et al., $2009{ }^{18}$ & France & Biopsy & 30 & IR/DM (+); BMI/WC (-); Dyslipidemia (-); ART (-); HIV (-) \\
\hline Akhtar et al., $2008^{12}$ & USA & Biopsy & 23 & $\begin{array}{l}\text { BMI/WC (+); ART (+), all patients who presented DHGNA were } \\
\text { exposed to NRTIs; HIV (+) }\end{array}$ \\
\hline Guaraldi et al., $2008^{16}$ & Italy & Computer Tomography & 225 & $\begin{array}{l}\text { IR/DM (+); BMI/WC and Visceral Adipose Tissue (+); Dyslipidemia } \\
(+) \text {; aminotransferases elevation (+); ART }(+) \text {, exposure to NRTIs }\end{array}$ \\
\hline Mohammed et al., $2007^{13}$ & Canada & Biopsy & 26 & BMI/WC (-); Dyslipidemia (+), hypertriglyceridemia; \\
\hline
\end{tabular}

$(+)$ : Associated factor present, (-): Associated factor absent; IR: insulin resistance; DM: diabetes mellitus; BMI: body mass index; WC: waist circumference; ART: antiretroviral therapy; NRTIs: Nucleoside Reverse Transcriptase Inhibitors; HIV: human immunodeficiency virus. 
body mass index (BMI) or waist circumference (WC) in six of eight studies ${ }^{11,12,15-17,19}$, dyslipidemia in six of seven studies; hypertriglyceridemia was present in all studies $^{2,11,13,15-17}$, and aminotransferases were elevated in five out of five studies $2,8,15,16,19$.

Five of eight studies found a negative association between HART therapy and NAFLD/NASH ${ }^{2,11,15-18}$. A positive association was limited to only three studies, in which reverse transcriptase nucleotide inhibitors (NRTIs) were the most commonly reported cause of NAFLD ${ }^{12,16,19}$. The viral load also was not associated with NAFLD/NASH in three of five studies ${ }^{10,18,19}$, and one study associated the prolonged duration of HIV infection with NAFLD/NASH ${ }^{2}$. All were cross-sectional studies.

FIGURE 2. PREVALENCE OF NONALCOHOLIC FATTY LIVER DISEASE ACCORDING TO THE SAMPLE SELECTION CRITERIA.

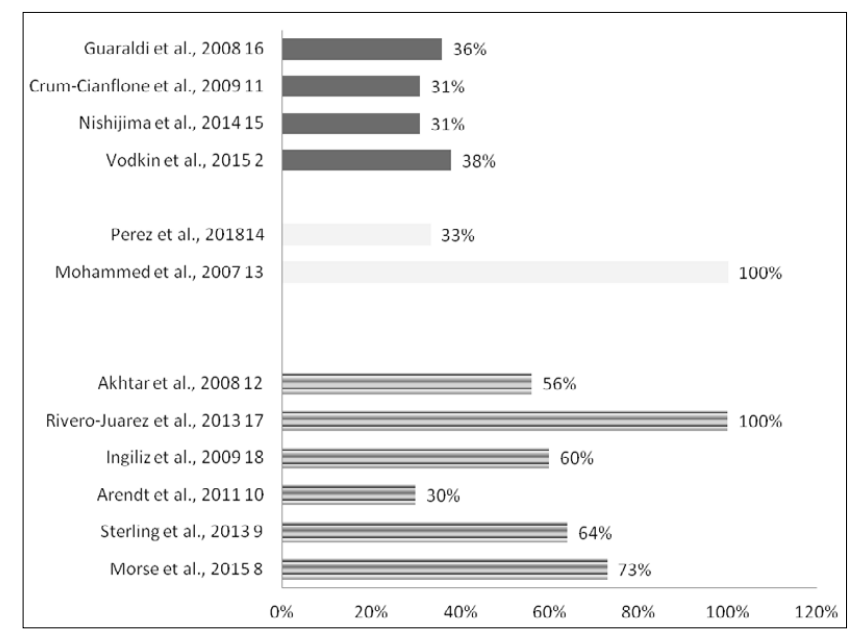

Patients with elevated aminotransferases; Patients with NAFLD; Randomly selected patients

\section{DISCUSSION}

The present systematic review observed an elevated prevalence of NAFLD in HIV infected patients, which ranged from $30 \%$ to $100 \%$ of the cases. However, the selection of patients did not use similar methodologies. In several studies, the patients were diagnosed by imaging methods ${ }^{10,15,16}$ and in others by liver biopsy. In randomized trials, less variation in the prevalence of NAFLD (31\% to $38 \%$ ) was observed.

Another factor that should be considered is the patients' selection for these studies. The samples from patients with HIV selected from the previous elevation of aminotransferases or after ruling out other causes of liver diseases could also influence the higher prevalence of NAFLD.
The liver biopsy is still the most effective method for staging NAFLD, diagnosing its various stages of steatosis, and differentiating NASH. However, it is considered an invasive method, is not free of complications, and has high costs.

The review has shown that MRI is more sensitive compared to USG to identify smaller amounts of fat ${ }^{20}$. The largest series in this review used imaging methods to diagnose steatosis ${ }^{11,15,16}$. Crum-Cianflone et al. ${ }^{11}$ added liver biopsy to 55 patients who had abnormalities in USG and/or elevated liver enzymes. The results indicated a prevalence of NASH in these patients.

The prevalence of NAFLD was also documented in studies performed in the USA, Japan, and Italy, before the results reported for these 13 studies included in this review. In 2000, a study of 126 patients in the USA to evaluate possible living donors found $20 \%$ of steatosis greater than $30 \%{ }^{21}$. A study conducted in Italy with 3,345 patients diagnosed $20 \%$ of NAFLD by USG in individuals without suspected liver disease ${ }^{22}$. In Japan, a cohort of 35,519 individuals showed an increase in NAFLD prevalence from $12.6 \%$ to $30.3 \%$ in 12 years $^{23}$. These data then indicate a higher prevalence of NAFLD in HIV-infected individuals.

Some authors ${ }^{6,18}$ suggested that insulin resistance (IR) was associated with antiretroviral therapy (ART), and others ${ }^{9,16,19}$ hypothesize that IR may be a product of common lipodystrophy in HIV-infected patients in use of ART or that IR could also be associated with hypertriglyceridemia secondary to ART ${ }^{17}$.

In some studies, on HIV-infected patients, NAFLD was associated with metabolic factors such as obesity and dyslipidemia, especially hypertriglyceridemia ${ }^{13}$, and it also has been suggested that abdominal obesity is an important predictor of NAFLD. Central obesity has been related to elevated levels of adiponectin and leptin, and these cytokines have been involved with IR and hepatic steatosis.

Although most of the studies in this review have suggested that metabolic factors are relevant for the development of NAFLD/NASH in HIV-infected patient, the relationship of NAFLD in these patients with ART, mainly D analogs (didanosine/ddI, stavudine/d4T, and zalcitabine/ddC) have been discussed. All these drugs can promote hepatocyte mitochondrial toxicity, lactic acidosis, and hepatic steatosis. However, the results have been controversial ${ }^{15,17,19}$.

This systematic review has some limitation: the causal relationships and natural history of HIV infection and NAFLD cannot be confirmed in these 
patients because most studies were cross-sectional; the differences in sample selection and the method used for the diagnosis of NAFLD; and the difficulty in estimating the overall prevalence of NAFLD in patients with HIV.

\section{CONCLUSION}

In conclusion, this review showed that there is a high prevalence of NAFLD in HIV patients; the HIV-infection treatment has increased the quality of life in these patients, although it also increased the prevalence of obesity and, consequently, NAFLD in this population. Metabolic factors are the most frequent risk factors of NAFLD in HIV patients, although a possible association between antiretroviral therapy and NAFLD has been suggested.

\section{Disclosure}

The authors report no conflict of interest.

\section{Funding statement}

The authors were responsible for the manuscript's financial support.

\section{Author Contributions}

Conceived and designed the experiments: LBP, RR, CD, and HPC. Performed the experiments: LBP, RR. Analyzed the data: LBP, RR, CD, HPC. Wrote the paper: LBP, RR, DV, CD, VC, VC, VS, HPC.

\section{RESUMO}

OBJETIVO: Avaliar a relevância da doença hepática gordurosa não alcoólica (DHGNA) em pacientes com HIV / AIDS.

MÉTODOS: A revisão sistemática foi realizada utilizando instrumentos de busca de material científico indexado, incluindo MEDLINE (pela PubMed), Web of Science, IBECS e LILACS. Estudos elegíveis incluíram o ano de publicação, critérios para diagnostico de DHGNA e HIV, publicados em inglês, português e espanhol, entre 2006 a 2018. Os critérios de exclusão incluíram estudos com pacientes com outras doenças do fígado. Dois revisores foram envolvidos na pesquisa dos artigos e o PRISMA (Preferred Reporting Items for Systematic Reviews and Meta - Analyses) foi utilizado nas análises.

RESULTADOS: Cento e dezesseis artigos foram selecionados, 27 excluídos porque não preencheram critérios de inclusão e assim, 89 foram lidos pelos investigadores. Desses, 13 artigos foram incluídos na revisão. Quatro séries de casos utilizaram métodos por imagens para identificação de DHGNA e nove estudos utilizaram biópsia hepática. A prevalência de DHGNA em pacientes com HIV variou de $30 \%$ a 100\% e esteato-hepatite não alcoólica (EHNA) entre 20\% e 89\%. Na avaliação das principais variáveis estudadas, observou-se a associação positiva entre dislipidemia, resistência à insulina e índice de massa corporal. Não houve concordância entre os artigos que avaliaram a relação dos antiretrovirais com a DHGNA.

CONCLUSÕES: A presente revisão sistemática sugere elevada prevalência de DHGNA em pacientes infectados com HIV. DHGNA nesses pacientes foi associada principalmente a fatores metabólicos. A possível associação entre terapia antiretroviral e DHGNA nesses pacientes vem sendo discutida, mas são necessários mais estudos para estabelecer essa associação.

PALAVRAS-CHAVE: Hepatopatia gordurosa não alcoólica. Infecções pelo HIV. Síndrome de Imunodeficiência Adquirida.

\section{REFERENCES}

1. UNAIDS. Get on the fast-track: the life-cycle approach to HIV, 2016. 140p. [cited 2019 Mar 15]. Available from: http://www.unaids.org/en/resources/ documents/2016/get-on-the-fast-track.

2. Vodkin I, Valasek MA, Bettencourt R, Cachay E, Loomba R. Clinical, biochemical and histological differences between HIV- associated NAFLD and primary NAFLD: a case-control study. Aliment Pharmacol Ther. 2015;41(4):368-78

3. Ong $\mid \mathrm{P}$, Younossi ZM. Epidemiology and natural history of NAFLD and NASH. Clin Liver Dis. 2007;11(1):1-16.

4. Dyson JK, Anstee QM, McPherson S. Non-alcoholic fatty liver disease: a practical approach to diagnosis and staging. Frontline Gastroenterol. 2014;5(3):211-8

5. Angelico F, Del Ben M, Conti R, Francioso S, Feole K, Fiorello S, et al. Insulin resistance, the methabolic syndrome, and nonalcoholic fatty liver disease. J Clin Endocrinol Metab. 2005;90(3):1578-82.

6. Guaraldi G, Lonardo A, Ballestri S, Zona S, Stentarelli C, Orlando G, et al. Human immunodeficiency virus is the major determinant of steatosis and hepatitis $\mathrm{C}$ virus of insulin resistance in virus-associated fatty liver disease. Arch Med Res. 2011;42(8):690-7.
7. Moher D, Liberati A, Tetzlaff J, Altman DG; PRISMA Group. Preferred reporting items for systematic reviews and meta-analyses: the PRISMA statement. PloS Med. 2009;6(7):e1000097.

8. Morse CG, McLaughlin M, Matthews L, Proschan M, Thomas F, Gharib AM, et al. Nonalcoholic steatohepatitis and hepatic fibrosis in HIV-1-monoinfected adults with elevated aminotransferase levels on antiretroviral therapy. Clin Infect Dis. 2015;60(10):1569-78.

9. Sterling RK, Smith PG, Brunt EM. Hepatic steatosis in human immunodeficiency virus: a prospective study in patients without viral hepatitis, diabetes, or alcohol abuse. J Clin Gastroenterol. 2013;47(2):182-7.

10. Arendt BM, Mohammed SS, Ma DW, Aghdassi E, Salit IE, Wong DK, et al. Non-alcoholic fatty liver disease in HIV infection associated with altered hepatic fatty acid composition. Curr HIV Res. 2011;9(2):128-35.

11. Crum-Cianflone N, Dilay A, Collins G, Asher D, Campin R, Medina S, et al. Nonalcoholic fatty liver disease among HIV-infected persons. I Acquir Immune Defic Syndr. 2009;50(5):464-73.

12. Akhtar MA, Mathieson K, Arey B, Post J, Prevette R, Hillier A, et al. Hepatic histopathology and clinical characteristics associated with antiretroviral therapy in HIV patients without viral hepatitis. Eur J Gastroenterol Hepatol. 2008;20(12):1194-204. 
13. Mohammed SS, Aghdassi E, Salit IE, Avand G, Sherman M, Guindi M, et al. HIV-positive patients with nonalcoholic fatty liver disease have a lower body mass index and are more physically active than HIV-negative patients. | Acquir Immune Defic Syndr. 2007;45(4):432-8.

14. Moreno-Perez $O$, Reyes-Garcia R, Muñoz-Torres M, Merino E, Boix V, Reus $S$, et al. High Irisin levels in nondiabetic HIV-infected males are associated with insulin resistance, nonalcoholic fatty liver disease, and subclinical atherosclerosis. Clin Endocrinol (Oxf). 2018;89(4):414-23.

15. Nishijima T, Gatanaga H, Shimbo T, Komatsu H, Nozaki Y, Nagata N, et al. Traditional but not HIV-related factors are associated with nonalcoholic fatty liver disease in Asian patients with HIV-1 infection. PLoS One. 2014;9(1):e87596.

16. Guaraldi G, Squillace N, Stentarelli C, Orlando G, D'Amico R, Ligabue G, et al. Nonalcoholic fatty liver disease in HIV-infected patients referred to a metabolic clinic: prevalence, characteristics, and predictors. Clin Infect Dis 2008;47(2):250-7

17. Rivero-Juárez A, Camacho A, Merchante N, Pérez-Camacho I, Macias |, Ortiz-Garcia C, et al; Grupo para el estudio de las hepatitis víricas (HEPAVIR) de la Sociedad Andaluza de Enfermedades Infecciosas (SAEI). Incidence of liver damage of uncertain origin in HIV patients not co-infected with HCV/ HBV. PLoS One. 2013;8(7):e68953.
18. Ingiliz P, Valantin MA, Duvivier C, Medja F, Dominguez S, Charlotte F, et al. Liver damage underlying unexplained transaminase elevation in human immunodeficiency virus-1 mono-infected patients on antiretroviral therapy. Hepatology. 2009;49(2):436-42.

19. Price JC, Seaberg EC, Latanich R, Budoff MJ, Kingsley LA, Palella FJ Jr, et al. Risk factors for fatty liver in the Multicenter AIDS Cohort Study. Am J Gastroenterol. 2014;109(5):695-704.

20. Sociedade Brasileira de Hepatologia. Doença hepática gordurosa não alcoólica [Internet]. São Paulo: Ed. Atha. [cited 2019 Mar 15]. Available from: http://www.sbhepatologia.org.br/pdf/revista_monotematico_hepato.pdf

21. Marcos A, Fisher RA, Ham IM, Olzinski AT, Shiffman ML, Sanyal Al, et al. Selection and outcome of living donors for adult to adult right lobe transplantation. Transplantation. 2000;69(11):2410-5.

22. Bedogni G, Miglioli L, Masutti F, Tiribelli C, Marchesini G, Bellentani S. Prevalence of and risk factors for nonalcoholic fatty liver disease: the Dionysos nutrition and liver study. Hepatology. 2005;42(1):44-52.

23. Kojima S, Watanabe N, Numata M, Ogawa T, Matsuzaki S. Increase in the prevalence of fatty liver in Japan over the past 12 years: analysis of clinical background. | Gastroenterol. 2003;38(10):954-61. 